Shapeshifters in Medieval North Atlantic Literature 


\section{The Early Medieval North Atlantic}

This series provides a publishing platform for research on the history, cultures, and societies that laced the North Sea from the Migration Period at the twilight of the Roman Empire to the eleventh century.

The point of departure for this series is the commitment to regarding the North Atlantic as a centre, rather than a periphery, thus connecting the histories of peoples and communities traditionally treated in isolation: Anglo-Saxons, Scandinavians/Vikings, Celtic communities, Baltic communities, the Franks, etc. From this perspective new insights can be made into processes of transformation, economic and cultural exchange, the formation of identities, etc. It also allows for the inclusion of more distant cultures - such as Greenland, North America, and Russia - which are of increasing interest to scholars in this research context.

Series Editors

Marjolein Stern, Gent University

Charlene Eska, Virginia Tech

Julianna Grigg, Monash University 


\title{
Shapeshifters in Medieval North Atlantic Literature
}

\author{
Edited by \\ Santiago Barreiro and Luciana Cordo Russo
}


Cover illustration: based on a detail from the U1163 Runestone from Drävle, Sweden Drawing by the authors

Cover design: Coördesign, Leiden

Lay-out: Crius Group, Hulshout

$\begin{array}{ll}\text { ISBN } & 9789462984479 \\ \text { e-ISBN } & 9789048535132 \text { (pdf) } \\ \text { DOI } & 10.5117 / 9789462984479 \\ \text { NUR } & 684\end{array}$

(c) Santiago Barreiro \& Luciana Cordo Russo / Amsterdam University Press B.V., Amsterdam 2019

All rights reserved. Without limiting the rights under copyright reserved above, no part of this book may be reproduced, stored in or introduced into a retrieval system, or transmitted, in any form or by any means (electronic, mechanical, photocopying, recording or otherwise) without the written permission of both the copyright owner and the author of the book. 